\title{
Evaluation of insecticide resistance and underlying resistance mechanisms in selected whitefly populations in Sri Lanka
}

\author{
JP Marasinghe ${ }^{1}$ and SHPP Karunaratne ${ }^{2 *}$ \\ ${ }^{I}$ Horticulture Research and Development Institute, Department of Agriculture, Peradeniya. \\ ${ }^{2}$ Department of Zoology, Faculty of Science, University of Peradeniya, Peradeniya.
}

Submitted: 25 November 2020; Revised: 22 February 2021; Accepted: 23 April 2021

\begin{abstract}
Whiteflies Bemisia tabaci and Trialeurodes vaporariorum cause high economic damage to commercial crops in Sri Lanka. Insecticide resistance was tested in $B$. tabaci collected from Kandy, Anuradhapura, Badulla, Matale and Hambantota districts and T. vaporariorum collected from Puttlam District against six insecticides using leaf dip bioassays. $\mathrm{LC}_{50}$ values and percentage mortalities for the recommended dosages were determined by log-probit mortality curves. Metabolic resistance caused by increased activities of esterases, glutathione S-transferases and cytochrome $\mathrm{P}_{450}{ }^{-}$ monooxygenases, and the insensitive target site resistance caused by acetylcholinesterases were evaluated by biochemical assays. Overexpression of CYP6CM1 monooxygenase protein in $B$. tabaci was tested using a lateral flow assay kit. The highest and the lowest resistance factors (RFs) were obtained for etofenprox (1311) and profenofos (4), respectively. Resistance percentages of whitefly populations to the recommended dosages were $37-83 \%$ for thiamethoxam, $50-83 \%$ for acetamiprid, $71 \%$ for imidacloprid, $2-36 \%$ for profenofos, $15-53 \%$ for carbosulfan and $68-89 \%$ for etofenprox. Anuradhapura, Badulla and Matale populations had elevated esterases, all populations had elevated GST activities and Badulla population had elevated monooxygenase activities. Populations were homozygous resistant or heterozygous for altered acetylcholinesterase mechanism. High esterase activities were parallel to high neonicotinoid resistance. CYP6CM1 overexpression was linked to thiamethoxam resistance than to acetamiprid resistance. Both the enhanced esterases and altered target sites were associated with high carbosulfan resistance. This is the first report on the insecticide resistance mechanisms of whiteflies in Sri Lanka. The outcome of the present study can be effectively utilized for a proper whitefly control programme in Sri Lanka, avoiding indiscriminate insecticide usage.
\end{abstract}

Keywords: CYP6CM1, insecticide resistance, insensitive acetylcholinesterases, metabolic resistance, whiteflies.

\section{INTRODUCTION}

Whiteflies in vegetables cause extensive economic damage. The silverleaf whitefly, Bemisia tabaci (Gennadius) (Insecta: Hemiptera: Aleyrodidae) is a injurious pest in agriculture (Bedford et al., 1994) and listed as one of the 100 worst invasive species in the world (Global Invasive Species Database, http:// www.issg.org/database). The greenhouse whitefly, Trialeurodes vaporariorum (Westwood) (Insecta: Hemiptera: Aleyrodidae), although not included in the invasive species list, is considered as another injurious whitefly present globally (Brødsgaard \& Albajes, 1999; Karatolos, 2011). In Sri Lanka, both B. tabaci and $T$. vaporariorum cause high economic damage to commercial crops. The number of host plant species of B. tabaci has been estimated to be more than 600 plant species (Basu, 1995) whereas T. vaporariorum is also known as a highly polyphagous species having a wide host plant range (Brødsgaard \& Albajes, 1999). However, the host range of these pests could be even higher at present with its wider global distribution. Out of all the whiteflies, B. tabaci has become prominent because of its ability to transmit a large number of begomoviruses causing complete destruction of crops (Brown \& Bird, 1992). Bemisia tabaci is now considered as a cryptic species complex, rather than different biotypes, due to

\footnotetext{
*Corresponding author (shppk@pdn.ac.lk; (iD https://orcid.org/0000-0002-2537-0548)
} 
high genetic varaitions found among populations (De Barro et al., 2011). Both the physiological traits and genetic variations are crucial in determining its species status, and Surendran et al. (2019) had identified that the predominant species type of B. tabaci in Sri Lanka is Asia-I.

Naturally, the control of whiteflies is difficult due to their high reproductive rate, wide host range and habit of lodging underneath leaves. On top of these natural features, the acquired resistance to insecticides by them is the most challenging at present. Insecticide resistance of whiteflies is a global issue. Bemisia tabaci is found to be resistant to more than 40 active ingredients used worldwide (Arthropod Pesticide Resistance Database, www.pesticideresistance.org). In brief, insecticide resistance is a heritable trait acquired by a population to withstand the toxicity of an insecticide repeatedly at its recommended dosage (Insecticide resistance action committee, https://irac-online.org/about/resistance). High resistance of $T$. vaporariorum to many insecticide groups including pyrethroids, organophosphates and neonicotinoids has been documented elsewhere (Cahill et al., 1995; Gorman et al., 2002; Nauen \& Denholm, 2005; Karatolos, 2011). The two major mechanisms of insecticide resistance in insects are; increased metabolism or detoxification by enzymes (mainly through esterases, mono-oxygenases and glutathione-S-transferases), and target site insensitivity by mutations (i.e. altered sodium channels for pyrethroids, altered acetylcholinesterase for organophosphates and carbamates, and altered nicotinic acetylcholine receptors for neonicotinoids) (Karunaratne, 1998; WHO, 1998).

Previously, we reported high resistance to insecticides in three whitefly populations based on laboratory bioassays raising concerns over the existing dosages recommended for chemical control (Marasinghe et al., 2017). The objective of the present study was to investigate the present status of whitefly resistance to insecticides in more detail by analysing the whitefly populations collected from six districts of the country against three neonicotinoids, one organophosphate, one carbamate and one pyrethroid. The activities of metabolic enzymes and altered acetylcholinesterase target site were also evaluated to understand the mechanisms underlying the insecticide resistance of this injurious pest category.

\section{METHODOLOGY}

\section{Whiteflies}

Bemisia tabaci populations were collected from several intensive agricultural localities from five districts belonging to four agroecological zones of Sri Lanka, i.e. Gannoruwa in Kandy, Huruluwewa in Anuradhapura, Bandarawela in Badulla, Matale in Matale, Suriyawewa in Hambantota and Kalpitiya in Puttalam. All collections were made during the 2016-2018 period and the details are given in Table 1. Bemisia tabaci collected from Puttalam were not enough for experiments. Trialeurodes vaporariorum dominated the whitefly collections from Puttalam district, and those samples were used for experiments for comparison.

Whiteflies were transported to the entomology laboratory of the Horticulture Research and Development Institute, Gannoruwa in cool boxes within few hours of collection. They were reared separately on young brinjal, tomato or cucumber plants in fine-mesh aluminium cages of $80 \times 40 \times 60 \mathrm{~cm}^{3}$ under room temperature up to 5-6 generations.

Species identification of both species were reconfirmed using adult/nymphal phenotypic features and the egg-laying pattern, i.e. B. tabaci adults are yellowish in colour and comparatively smaller with wings held vertical and parallel to body axis at rest. The fourth instar nymph (pupa) is almost circular in shape without

Table 1: Whitefly collection localities and associated host plants

\begin{tabular}{lccc}
\hline Locality / district & Collected species & Agricultural zone & Host plants \\
\hline Gannoruwa/Kandy & Bemisia tabaci & Mid country wet & Tomato, Brinjal, Cucurbits \\
Huruluwewa/Anuradhapura & B. tabaci & Low country dry & Brinjal, Cucurbits \\
Bandarawela/Badulla & B. tabaci & Up country intermediate & Brinjal, Bean, Tomato \\
Matale/Matale & B. tabaci & Mid country intermediate & Brinjal \\
Suriyawewa/Hambantota & B. tabaci & Low country dry & Brinjal \\
Kalpitiya/Puttlam & Trialeurodes vaporariorum & Low country dry & Brinjal, Cucurbits \\
\hline
\end{tabular}


long threads. Eggs are laid in a scattered manner on the underside of host leaf. Trialeurodes vaporariorum adults hold their wings in a flattened and overlapped position at rest. The fourth instar nymph is oval/ elliptical in shape with long erect threads. Eggs are laid in a circular pattern on the underside of the host leaf. Slide-mounted pupae were also examined for characteristic morphological features to differentiate the two species (Hodges \& Evans, 2005). A set of specimens from each population was stored at $-20{ }^{\circ} \mathrm{C}$ for biochemical assays.

\section{Chemicals and equipment}

Chemicals were purchased from Sigma Chemicals, UK unless otherwise stated. Formulated insecticides of thiamethoxam (Actara from Deccan Fine ChemicalsIndia Pvt Ltd.), acetamiprid (Mospilan from Nippon Soda Company Ltd.), imidacloprid (Admire from Bayer A.G. Crop Science, Germany), profenofos (Calcron from Coromandel International Ltd., India), carbosulfan (Marshal from FMC Corporation, USA), etofenprox (Trebon from Mitsui Chemicals Agro Inc., Japan) were purchased from the agrochemical sales outlets in Kandy, Sri Lanka. UVmaxELx800TM absorbance microplate reader was from Molecular devices, Bio-Tek, USA. Protein assay kit was purchased from BIO-RAD, UK. Whitefly test kit for the detection of CNI (neonicotinoid) resistance was a gift from Bayer CropScience AG, Germany.

\section{Bioassays}

Bioassays were carried out with three neonicotinoids (thiamethoxam 25\% WG, acetamiprid 20\% SP and imidacloprid 70\% WG), an organophosphate (profenofos $500 \mathrm{~g} / \mathrm{L} \mathrm{SC}$ ), a carbamate (carbosulfan $200 \mathrm{~g} / \mathrm{L} \mathrm{SC}$ ) and a pyrethroid (etofenprox $100 \mathrm{~g} / \mathrm{L}$ EC) using leaf dip method as previously described (IRAC, 2009; Marasinghe et al., 2017). In brief, squarecut brinjal leaves $\left(3 \times 3 \mathrm{~cm}^{2}\right)$ were immersed in aqueous solutions of insecticides for $5 \mathrm{~s}$ and then air dried. Thirty whiteflies were exposed to each insecticide-treated squarecut leaf held in ventilated transparent containers. The containers were kept under normal day/night conditions at room temperature for 24 h. Seven to eight concentrations of each insecticide (five replicates with 150 whiteflies per concentration) that gave mortalities between 0 to $100 \%$ were used for testing each population, i.e. thiamethoxam 10, 100, 250, 1000, 2500, 5000, 1000 ppm; acetamiprid 10, 100, 200, 500, 1000, 2000, 5000, 10000 ppm; carbosulfan 10, 100, 300, $500,1000,2000,5000,10000 \mathrm{ppm}$; imidacloprid 10, 100, 200, 500, 1000, 2000, 5000, 10000 ppm; etofenprox 10, $100,500,1000,2000,10000,15000 \mathrm{ppm}$ and profenofos
10, 50, 100, 250, 500, 800, 1000, 2000 ppm. Distilled water without insecticides was used as the control. Final mortality was assessed after the $24 \mathrm{~h}$ exposure period.

\section{Biochemical assays}

Adult whiteflies in batches of 20 individuals totalling up to a minimum of 200 individuals from each population were subjected to esterase, glutathione S-transferase (GST), monooxygenase, protein and acetylcholinesterase assays using a kinetic microplate reader (Bio-Tek, USA). Mass homogenates of the batches of 20 whiteflies were prepared separately in $150 \mu \mathrm{L}$ of distilled water. Crude homogenate was directly used for acetylcholine esterase assay. The supernatant after centrifugation for $2 \mathrm{~min}$ at $10,000 \mathrm{~g}$ was used for esterase, GST, monooxygenase and protein assays. All the biochemical assays were carried out in microtiter plates. All the tests were replicated and controls were run with distilled water instead of the crude homogenate or supernatant. The assaying methods described in the Field and Laboratory Manual of the World Health Organization (WHO, 1998) were adopted with slight modifications as previously described for agricultureal insect pests (Damayanthi \& Karunaratne, 2005; Karunaratne \& Weerakoon, 2007).

\section{Esterase assay}

Ten microlitres of homogenate was mixed with $200 \mu \mathrm{L}$ of $1 \mathrm{mM}$ p-nitrophenyl acetate (pNPA) working solution in $50 \mathrm{mM}$ sodium phosphate buffer (pH 7.4). At $405 \mathrm{~nm}$, the absorbance of the reaction was measured kinetically for $2 \mathrm{~min}$ and converted to moles using an extinction coefficient of $6.53 \mathrm{mM}^{-1}$ (corrected for a path length of $0.6 \mathrm{~cm})$.

\section{Glutathione S-transferase (GST) assay}

Ten microlitres of homogenate was mixed with $200 \mu \mathrm{L}$ of substrate solution prepared using $10.5 \mathrm{mM}$ reduced glutathione ( 95 parts GSH in $100 \mathrm{mM}$ phosphate buffer) and $63 \mathrm{mM}$ 1-chloro-2,4-dinitrobenzene (CDNB) (5 parts of CDNB in methanol). The reaction rate was measured at $340 \mathrm{~nm}$ for $5 \mathrm{~min}$. The absorbance was converted to moles using an extinction coefficient of $5.76 \mathrm{mM}^{-1}$ (corrected for a path length of $0.6 \mathrm{~cm}$ ).

\section{Monooxygenase assay}

Twenty microlitres of homogenate was mixed with $80 \mu \mathrm{L}$ potassium phosphate buffer $(\mathrm{pH} 7.2)+200 \mu \mathrm{L} 6.3 \mathrm{mM}$ tetramethyl benzidine (TMBZ) working solution $(0.01 \mathrm{~g}$ TMBZ dissolved in $5 \mathrm{~mL}$ methanol and then in $15 \mathrm{~mL}$ 
of sodium acetate buffer at $\mathrm{pH} 5.0)+25 \mu \mathrm{L}$ of $3 \% \mathrm{H}_{2} \mathrm{O}_{2}$ solution in a microtitre plate well. The mixture was left for $2 \mathrm{~h}$ for incubation under room temperature and the absorbance was read as an end point assay at $630 \mathrm{~nm}$. The amount of monooxygenase was expressed as equivalent units of cytochrome $\mathrm{P}^{450}$ (Brogdon et al., 1997).

\section{Protein assay}

Protein assays were conducted to obtain protein concentrations of the homogenates to determine specific activities of the enzymes. BIO-RAD protein determination kit, with bovine serum albumin as the standard protein was used. Ten microlitres of the homogenate was mixed with $300 \mu \mathrm{L}$ of BIO-RAD working solution (prepared according to the manufacturer's instructions) and after a 5 min incubation period at room temperature, the reaction was read at $570 \mathrm{~nm}$ as an end point assay.

\section{Acetylcholinesterase (AChE) assay}

Two $\times 25 \mu \mathrm{L}$ of crude homogenate were placed in two consecutive wells of a microtiter plate, each containing $145 \mu \mathrm{L}$ of $1 \%$ Triton buffer in $100 \mathrm{mM}$ phosphate buffer at $\mathrm{pH} 7.8$ with $10 \mu \mathrm{L}$ of $10 \mathrm{mM}$ dithiobis 2-nitrobenzoic acid $(0.0396 \mathrm{~g}$ of DTNB in $100 \mathrm{mM}$ phosphate buffer at $\mathrm{pH}$ 7.0). An aliquote of $25 \mu \mathrm{L}$ of $10 \mathrm{mM}$ acetylthiocholine iodide (ASCHI) $(0.0578 \mathrm{~g}$ ASCHI in $20 \mathrm{~mL}$ distilled water) was added to one of the wells while $25 \mu \mathrm{L}$ of $10 \mathrm{mM}$ ASCHI with propoxur ( $10 \mathrm{~mL}$ of $10 \mathrm{mM}$ ASCHI $+20 \mu \mathrm{L}$ of $0.1 \mathrm{M}$ propoxur in acetone) was added to the other. Acetylcholinestearse (AChE) activity was measured at $405 \mathrm{~nm}$ for $5 \mathrm{~min}$. Results were expressed as the percentage remaining activity in the inhibited fraction compared with the control (uninhibited) activity.

\section{Detection of the CYP6CM1 protein in B. tabaci}

A field portable ELISA based lateral flow assay designed to detect monooxygenase CYP6CM1 protein was used following the manufacture's protocol (Bayer CropScience). Five to ten whiteflies from each population were homogenised in conjugated polyclonal antibodies in a homogenization vial. After a 2-3 min incubation, streptavidin-gold solution was added to the vial and gently inverted 3-4 times. The mixture was then poured into the sample cavity of the test strip and observed for 5 min. Respective distinct lines at $\mathrm{C}$ and $\mathrm{T}$ points indicated the expression levels of the CYP6CM1 enzyme by the control and the sample, respectively.

\section{Data analysis}

Bioassay data were used only when the control mortality was less than $20 \%$. Mortalities were adjusted with control mortalities using Abbott's formula (Abbott, 1987). Adjusted mortalities were Probit transformed using Sigma Plot (version 10) software and plotted against the log values of the insecticide concentrations. The $\mathrm{LC}_{50}$ and the percent mortality for the Department of Agriculture recommended dosages (DOA, 2015) were estimated by regression analysis. Chi square values $\left(\chi^{2}\right)$ were calculated by evaluating the goodness-of-fit of the linear regression to log-probit transformed data. The software provides the slope and the $95 \%$ confidence limits for each mortality line. Resistance factors (RF) were calculated using $\mathrm{LC}_{50}$ values reported for susceptible populations of the same species elsewhere and used to evaluate resistance levels (Cahill et al., 1995; Karatolos, 2011; Vassiliou, 2011).

\section{RESULTS AND DISCUSSION}

A total of 48,989 whiteflies from B. tabaci and T. vaporariorum were subjected to insecticide bioassays. Probit analysis separately done for the bioassay results obtained for the six populations with six insecticides are shown in Table 2 together with RFs. For thiamethoxam, $\mathrm{LC}_{50}$ values of both $T$. vaporariorum and $B$. tabaci were in a similar range. However, the $\mathrm{LC}_{50}$ values estimated for profenofos, carbosulfan and etofenprox for $T$. vaporariorum were higher than those obtained for B. tabaci. Among B. tabaci populations, the highest and the lowest $\mathrm{LC}_{50}$ values for thiamethoxam were respectively detected from Badulla and Matale populations. In contrast, for acetamiprid, the highest and the lowest were respectively from Matale and Badulla populations. The highest and the lowest values for profenofos were from Badulla and Kandy populations, respectively. Matale and Hambantota populations showed the highest and lowest $\mathrm{LC}_{50}$ values, respectively, for carbosulfan, whereas Kandy and Matale populations gave the highest and the lowest $\mathrm{LC}_{50}$ values for etofenprox, respectively.

Chi square value $\left(\chi^{2}\right)$ gives the goodness-of-fit of a dose-mortality line and significant $\chi^{2}$ estimates indicate deviation from linear response showing a heterogeneity of the population. For etofenprox, all the populations except Matale exhibited a heterogeneous response. For the other insecticides tested, most of the whitefly populations showed a homogeneous response (Table 2). For carbosulfan, RFs could not be calculated 
since no $\mathrm{LC}_{50} \mathrm{~s}$ had been reported for susceptible whitefly populations. Similarly, no $\mathrm{LC}_{50} \mathrm{~s}$ were found for a susceptible T. vaporariorum for acetamiprid, profenofos and etofenprox. RFs were very high for etofenprox (281-1311) and the lowest RFs were estimated for profenofos (4-71) (Table 2).

Table 2: Log-dose probit mortality results obtained for bioassays conducted with whitefly populations of $B$. tabaci and T. vaporariorum against thiamethoxam, acetamiprid, imidacloprid, profenofos, carbosulfan and etofenprox. Trialeurodes vaporariorum was tested only from Puttalam and B. tabaci was tested only from all the other districts.

\begin{tabular}{|c|c|c|c|c|c|c|c|}
\hline Insecticide & Population & $\mathrm{N}$ & $\mathrm{LC}_{50} \mathrm{ppm}$ & $95 \% \mathrm{CI}$ & Slope & $\chi^{2}$ & $\mathrm{RF}$ \\
\hline \multirow[t]{6}{*}{ Thiamethoxam } & Kandy & 1710 & 579 & $282-1123$ & 0.61 & 8.9 & ${ }^{1} 127$ \\
\hline & Anuradhapura & 1365 & 294 & $109-447$ & 0.56 & 5.7 & ${ }^{1} 64$ \\
\hline & Badulla & 1093 & 1090 & 578-2024 & 0.86 & 12.7 & ${ }^{1} 239$ \\
\hline & Matale & 1472 & 25 & $<10-70$ & 0.68 & 5.0 & ${ }^{15}$ \\
\hline & Hambantota & 1751 & 223 & $53-605$ & 1.01 & $30.4 * * * *$ & ${ }^{1} 49$ \\
\hline & Puttalam & 1478 & 398 & $49-563$ & 0.70 & $14.5^{*}$ & ${ }^{2} 21$ \\
\hline \multirow[t]{6}{*}{ Acetamiprid } & Kandy & 1799 & 230 & $60-605$ & 0.87 & 13.3 & ${ }^{1} 23$ \\
\hline & Anuradhapura & 1814 & 1259 & $622-3703$ & 0.44 & 3.2 & ${ }^{1} 125$ \\
\hline & Badulla & 1739 & 208 & $121-321$ & 1.00 & 8.5 & ${ }^{1} 21$ \\
\hline & Matale & 1633 & 1753 & $930-4943$ & 1.0 & 9.7 & ${ }^{1} 172$ \\
\hline & Hambantota & 2051 & 985 & $278-5231$ & 0.76 & $43.1 * * * *$ & ${ }^{1} 98$ \\
\hline & Puttalam & NT & NT & NT & NT & NT & $\mathrm{NC}$ \\
\hline Imidacloprid & Puttalam & 1540 & 806 & $335-2240$ & 1.35 & $44.9 * * * *$ & ${ }^{2} 47$ \\
\hline \multirow[t]{6}{*}{ Profenofos } & Kandy & 1893 & 27 & $<10-61$ & 1.07 & 12 & ${ }^{3} 4$ \\
\hline & Anuradhapura & 1870 & 121 & $55-230$ & 1.21 & 5.6 & ${ }^{3} 20$ \\
\hline & Badulla & 1696 & 434 & $217-1562$ & 1.51 & $13.5^{*}$ & 371 \\
\hline & Matale & 1733 & 88 & $33-183$ & 1.55 & $35.7 * * * *$ & ${ }^{3} 14$ \\
\hline & Hambantota & 1432 & 58 & $16-126$ & 1.69 & $11.7^{*}$ & ${ }^{3} 10$ \\
\hline & Puttalam & 1754 & 509 & $355-817$ & 1.89 & 5.2 & $\mathrm{NC}$ \\
\hline \multirow[t]{6}{*}{ Carbosulfan } & Kandy & 1644 & 71 & $45-112$ & 0.7 & 0.9 & $\mathrm{NC}$ \\
\hline & Anuradhapura & 1775 & 321 & $211-434$ & 0.97 & 1.4 & $\mathrm{NC}$ \\
\hline & Badulla & 1513 & 237 & $17-531$ & 0.81 & 5.4 & $\mathrm{NC}$ \\
\hline & Matale & 1400 & 659 & $240-3073$ & 0.80 & $17.1 * *$ & $\mathrm{NC}$ \\
\hline & Hambantota & 953 & 12 & $<10-25$ & 0.59 & 0.2 & $\mathrm{NC}$ \\
\hline & Puttalam & 1761 & 760 & $371-1778$ & 0.79 & 12.5 & $\mathrm{NC}$ \\
\hline \multirow[t]{6}{*}{ Etofenprox } & Kandy & 1988 & 1704 & $795-3225$ & 1.02 & $12.6^{*}$ & ${ }^{3} 1311$ \\
\hline & Anuradhapura & 1890 & 587 & $274-1188$ & 0.93 & $15.4 *$ & ${ }^{3} 452$ \\
\hline & Badulla & 1567 & 1314 & 398-9306 & 0.82 & $31.1 * * * *$ & ${ }^{3} 1011$ \\
\hline & Matale & 1558 & 365 & $240-2699$ & 1.30 & 10.5 & ${ }^{3} 281$ \\
\hline & Hambantota & 1861 & 371 & $128-2240$ & 1.14 & $35.0 * * * *$ & ${ }^{3} 285$ \\
\hline & Puttalam & 1256 & 2512 & $1223-7830$ & 0.98 & $18.5^{* *}$ & $\mathrm{NC}$ \\
\hline
\end{tabular}

$\mathrm{N}$ - number tested; CI - confidence intervals; $\chi^{2}$ - chi square value evaluating the goodness-of-fit of the linear regression to log-probit transformed data; RF - resistance factor; ${ }^{*} \mathrm{p}<0.05 ; * * \mathrm{p}<0.01 ; * * * \mathrm{p}<0.001 ; * * * * \mathrm{p}<0.0001 ;{ }^{1}$ susceptible data used from Vassiliou et al. (2011), ${ }^{2}$ from Karatolos (2011), ${ }^{3}$ from Cahill et al. (1995); NT- not tested; NC- not calculated due to unavailability of susceptible data. 
Mortality of whitefly populations to the insecticide dosages recommended by the Department of Agriculture (DOA) of Sri Lanka (DOA, 2015) as determined by using the mortality curves are presented in Table 3. Percentage mortalities of populations varied from 11-98 \%. Whiteflies from Kandy, Matale and Hambanthota gave more than $90 \%$ mortalities for the DOA recommended profenofos dosage, and for other three districts 3-9 fold dose increment was required to achieve a $90 \%$ mortality. All the other tested insecticides required $3->80-$ fold increase of the recommended dosage to achieve
$90 \%$ mortality in these populations. Trialeurodes vaporariorum gave a similar mortality as for $B$. tabaci to DOA recommended dosage except for etofenprox, which showed a lower efficacy for $T$. vaporariorum (Table 3). Imidacloprid could be tested only against T. vaporariorum and $29 \%$ mortality obtained for the DOA recommended dosage indicates the high imidacloprid resistance in whiteflies. In general, high resistance to all the tested insecticides is evident in whitefly populations except for profenofos in a few populations (Table 3).

Table 3: Percentage mortalities estimated for B. Tabaci from Kandy, Anuradhapura, Badulla, Matale, Hambantota and T. vaporariorum from Puttalam, to the Department of Agriculture (DOA) recommended dosages of six insecticides

\begin{tabular}{|c|c|c|c|c|c|c|c|c|}
\hline \multirow[t]{2}{*}{ Insecticide } & \multirow{2}{*}{$\begin{array}{l}\text { Mode of } \\
\text { action* }\end{array}$} & \multirow{2}{*}{$\begin{array}{c}\text { DOA } \\
\text { recommended } \\
\text { dosage per } \\
16 \mathrm{~L} \text { tank }\end{array}$} & \multicolumn{6}{|c|}{ Percentage mortality } \\
\hline & & & Kandy & Anuradhapura & Badulla & Matale & Hambantota & Puttalam \\
\hline Thiamethoxam $25 \mathrm{WG}$ & $4 \mathrm{~A}$ & $8 \mathrm{~g}$ & $30 \%$ & $43 \%$ & $17 \%$ & $63 \%$ & $32 \%$ & $36 \%$ \\
\hline Acetamiprid $20 \mathrm{SP}$ & $4 \mathrm{~A}$ & $16 \mathrm{~g}$ & $50 \%$ & $39 \%$ & $49 \%$ & $17 \%$ & $29 \%$ & NT \\
\hline Imidacloprid $20 \mathrm{SL}$ & $4 \mathrm{~A}$ & $16 \mathrm{ml}$ & NT & NT & NT & NT & NT & $29 \%$ \\
\hline Profenofos 50 EC & 1B & $32 \mathrm{~mL}$ & $95 \%$ & $73 \%$ & $64 \%$ & $95 \%$ & $98 \%$ & $68 \%$ \\
\hline Carbosulfan $20 \mathrm{EC}$ & $1 \mathrm{~A}$ & $48 \mathrm{~mL}$ & $75 \%$ & $60 \%$ & $72 \%$ & $49 \%$ & $85 \%$ & $47 \%$ \\
\hline Etofenprox $10 \mathrm{EC}$ & $3 \mathrm{~A}$ & $24 \mathrm{~mL}$ & $13 \%$ & $30 \%$ & $20 \%$ & $31 \%$ & $32 \%$ & $11 \%$ \\
\hline
\end{tabular}

*as described by the Insecticide Resistance Action Committee: $4 \mathrm{~A}=$ nicotinic acetylcholinreceptor competitive modulators-neonicotinoids; $1 \mathrm{~B}=$ acetylcholinesterase inhibitors-organophosphates; $1 \mathrm{~A}=$ acetylcholinesterase inhibitors-carbamates; $3 \mathrm{~A}=$ sodium channel modulators-pyrethroids; NT - not tested

Both the species, B. tabaci and T. vaporariorum, had similar activity levels in their insecticide metabolizing enzymes (Figure 1). In B. tabaci, specific activities of esterases and GSTs were in the ranges of 0.180.35 and $1.25-1.71 \mu \mathrm{mol} / \mathrm{min} / \mathrm{mg}$, respectively. For $T$. vaporariorum, the respective values were 0.17 and $1.08 \mu \mathrm{mol} / \mathrm{min} / \mathrm{mg}$. Monooxygenase amounts in $B$. tabaci were in the range $0.02-0.50$ equivalent units of cytochrome $\mathrm{P}_{450}$ and that of $T$. vaporariorum was 0.02 . Vassiliou et al. (2011) have reported esterase and GST activities for a susceptible B. tabaci population. However, the esterase specific activities cannot be used to compare with the present results since the substrate used for the assay was different to that of the present study. Using the same methodology of the present study, a GST specific activity of $0.2 \mu \mathrm{mol} / \mathrm{mg} / \mathrm{min}$ has been obtained for their susceptible population, which is about 5-8 times lower than the GST activities detected in our whitefly populations (Vassiliou et al., 2011). No other enzyme activity data from susceptible strains are available for whiteflies or for any other insect pest of agriculture for comparison. However, for anopheline mosquitoes discriminating values are available in the literature for the same assays to determine the enhanced activities; above $0.25 \mu \mathrm{mol} / \mathrm{mg} / \mathrm{min}$ for enhanced esterase activity, above $0.40 \mu \mathrm{mol} / \mathrm{mg} / \mathrm{min}$ for enhanced GST activity, and 0.35 equivalent units of cytochrome $\mathrm{P}_{450}$ for enhanced monooxygenase amounts (Perera et al., 2008). According to this classification, Anuradhapura, Badulla and Matale populations have elevated esterases, all six whitefly populations have elevated GST activities and Badulla population has elevated monooxygenase activities (Figure 1). In aphids and mosquitoes, elevation of esterases is a powerful mechanism against organophosphates and carbamates, which have molecular structures rich with esterase bonds (Karunaratne et al., 2018). Thiamethoxam resistant B. tabaci has been synergized and reversed using the esterase inhibitor 
S,S,S-tributyl phosphorotrithioate (DEF) showing its importance in thiamethoxam resistance (Kandil et al., 2008). The present study also reveals high esterase activity levels parallel to high neonicotinoid resistance,

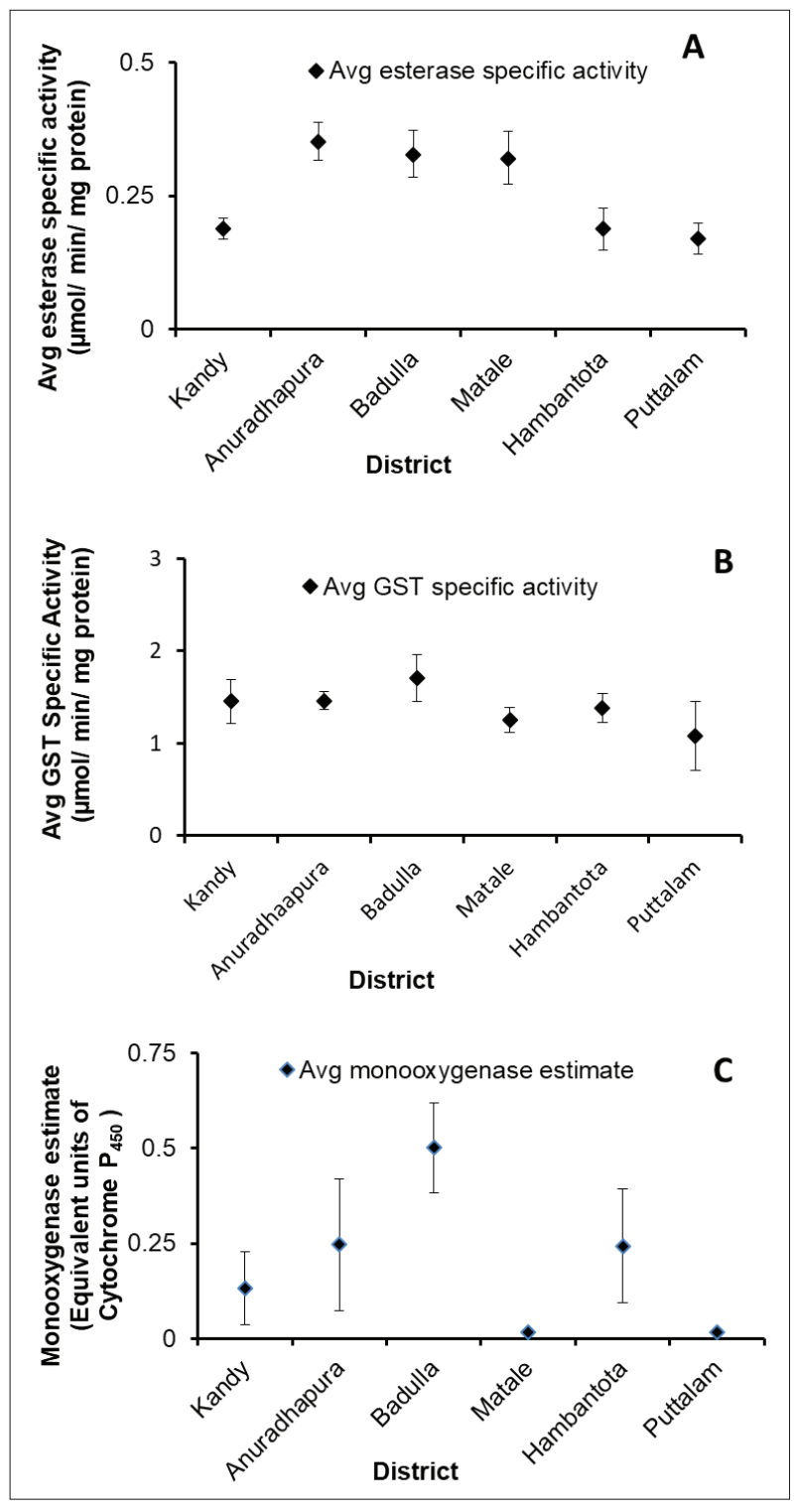

Figure 1: Insecticide metabolizing enzyme activities of whitefly populations. Trialeurodes vaporariorum was tested only from Puttalam and B. tabaci was tested only from all the other districts. A - esterase specific activity; B - glutathione-S-transferase (GST) specific activity; C - monooxygenase amounts in equivalent units of cytochrome $\mathrm{P}_{450}$. A minimum of 100 insects (five batches, 20 individuals per batch) were tested per assay per site. Error bars indicate the standard errors. indicating the contribution of esterases to neonicotinoid resistance. Although GSTs are primarily important in declorination of organochlorines, elevated levels of GST activity have been reported in organophosphate, organochlorine and pyrethroid resistant mosquitoes (Che-Mendoza et al., 2008). High GST levels observed in the studied whitefly populations may have a wider general role giving resistance to all insecticide groups.

Results of the ELISA based lateral flow assay for CYP6CM1 monooxygenase protein also showed a clear overexpression of CYP6CM1 monooxygenase protein in Badulla $B$. tabaci population (Figure 2). The CYP6CM1 expression levels of lateral flow assay nicely matched with the biochemical assay data indicating that CYP6CM1, a typical microsomal $\mathrm{P}_{450}$ member of CYP6 family, is a major candidate of enhanced monooxygenases of the tested whitefly populations. Imidacloprid resistance in both the $\mathrm{B}$ and $\mathrm{Q}$ biotypes of $B$. tabaci has been tightly related to the up-regulation of the cytochrome P450dependent monooxygenase gene CYP6CM1 (Karunker et al., 2008). Overexpression of CYP6CM1 gene has also been detected in thiamethoxam resistant $B$. tabaci too (Yang et al., 2013). Imidacloprid resistance in B. tabaci has not been tested in our study and thus, the association with imdicaloprid resistance could not be traced.

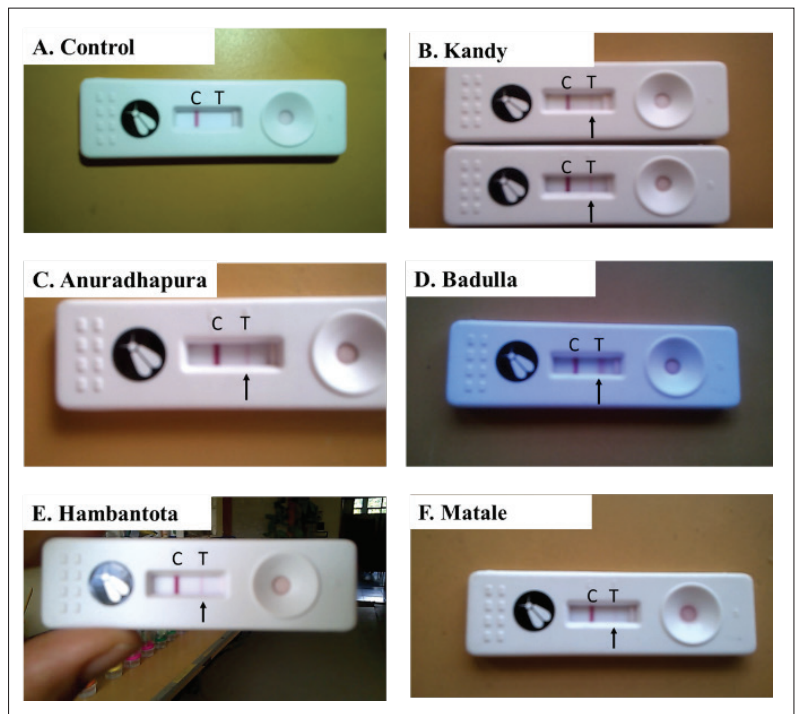

Figure 2: Monooxygenase CYP6CM1 expression level in B. tabaci populations from Kandy (B), Anuradhapura (C), Badulla (D), Hambantota (E) and Matale (F) as detected by the diagnostic kits. Control (A) does not show a $2^{\text {nd }}$ line; C control line; T - CYP6CM1 monooxygenase expression line 
According to our bioassay results from Badulla and Matale populations, it can be concluded that CYP6CM1 is more important in thiamethoxam resistance than in acetamiprid resistance.

Percentage remaining activities of propoxur inhibited target site $\mathrm{AChE}$ are shown in Figure 3. The same AChE assay is used by WHO to categorize mosquito populations as susceptible homozygous (SS)
( $<30 \%$ remaining activity), heterozygous (RS) $(30-70 \%$ remaining activity) and resistant homozygous (RR) (> $70 \%$ remaining activity) for altered or insensitive $\mathrm{AChE}$ target site mechanism (WHO, 2016). According to these guidelines, Badulla B. tabaci population was homozygous resistant with $>70 \%$ remaining activity while all other populations including $T$. vaporariorum population were heterozygous for altered $\mathrm{AChE}$ mechanism with a remaining activity of $30-70 \%$ (Figure 3 ).

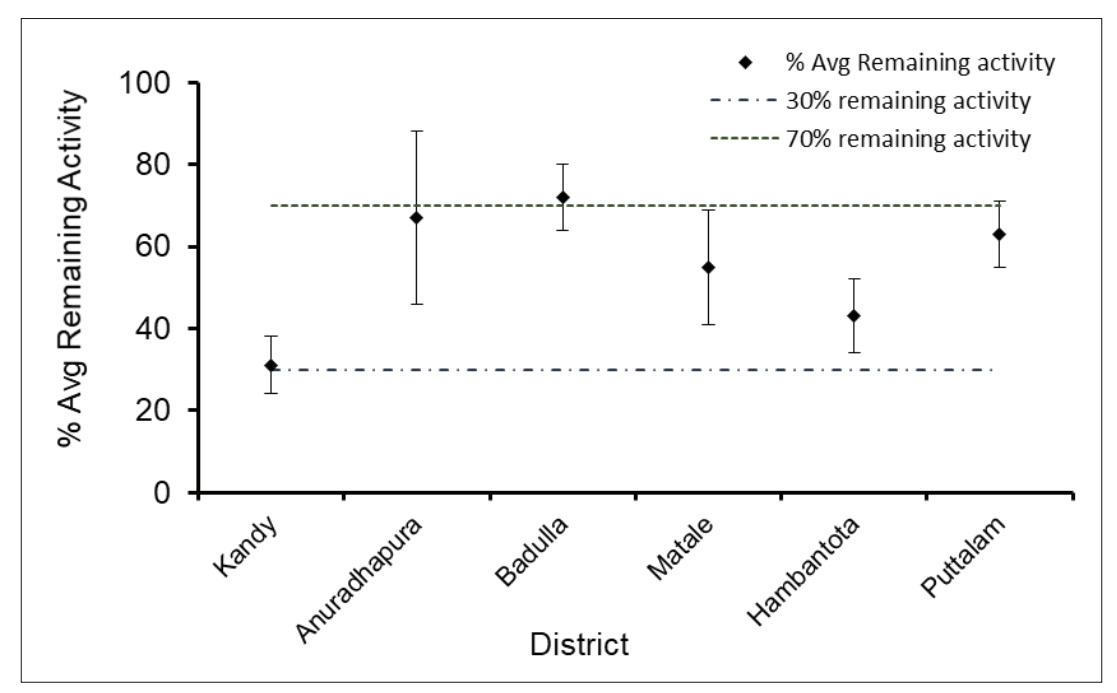

Figure 3: Percentage remaining activities of propoxur inhibited acetylcholine esterases of $B$. tabaci except for Puttalam where T. vaporariorum was tested. A minimum of 100 insects (five batches, 20 individuals per batch) were tested per assay per site. Two dotted lines show the WHO recommended discriminating remaining activities for mosquitoes ( $<30 \%$ susceptible; $30-70 \%$ heterozygous resistance; $>70 \%$ homozygous resistance) (WHO, 2016). Error bars indicate the standard errors.

High organophosphate and carbamate resistance is expected from the altered $\mathrm{AChE}$ target sites and elevated esterases activities (Karunaratne et al., 2018). Acetylcholinesterase insensitivity has been previously reported in OP and/or carbamate resistant whiteflies (Dittrich \& Ernst, 1990; Byrne \& Devonshire, 1991). Therefore, the high profenofos and carbosulfan resistance detected in Badulla and Matale districts for B. tabaci populations must be due to these two mechanisms.

Whitefly control has become a serious problem in agriculture due to reduced efficacy of recommended insecticides. Severity of the problem has intensified with the economical importance of B. tabaci being a begomovirus vector of many crops. A large number of insecticides belonging to different chemical groups have been recommended for whitefly control in Sri Lanka (MOAAL, 1997; DOA, 2009). Organophosphates and carbamates have a long history of use for more than 4 decades. Pyrethroids were introduced in the 1990s and neonicotinoids in early years of this century for whitefly control (DOA, 2009). The popularity of neonicotinoids among farmers increased not only due to their high efficacy at the introductory phase, but also due to the wide crop range applicability and the long residual activity. The present study evaluated the efficacy of representative samples of these insecticide groups against $B$. tabaci and $T$. vaporariorum using laboratory bioassays with the leaf dip method, which resembles the foliar application method practiced in the field. The percentage mortalities estimated using probit regression lines revealed high resistance of whiteflies to all the tested insecticides, 
except for profenofos. Since repeated use of less effective insecticides would further increase resistance generation with environment pollution, taking different approaches to control whiteflies at this stage is necessary. The underlying mechanisms of insecticide resistance in Sri Lankan whitefly populations were evaluated for the first time using biochemical assays. It was evident that both the metabolic resistance and insensitive target site resistance mechanisms have been developed to varying degrees in Sri Lankan whitefly populations. In T. vaporariorum also the resistance levels and resistance mechanisms are found to be comparable to those of B. tabaci.

Etofenprox is a non-ester pyrethroid having a mode of action similar to other pyrethroids, i.e. by interacting with voltage gated sodium channels (VGSC) of insect neurons. Cross resistance studies have shown no effect of enhanced metabolic enzyme activities on etofenprox toxicity in mosquitoes possibly due to the relatively simple structure of the etofenprox molecule compared to most of the other pyrethroids (Hemingway, 1995). Also, the monooxygenase synergist piperonyl butoxide (PBO) and GST synergist diethyl maleate (DEM) were able to synergize permethrin resistance, but not etofenprox resistance in Anopheles mosquitoes (Gross $\&$ Bloomquist, 2018). With the high resistance observed in all whitefly populations against etofenprox, and with a least chance for metabolic resistance mechanisms to be operative, there is a high possibility that knockdown type $(k d r)$ target site mutations are involved in this resistance. Future studies are required to investigate the presence of $k d r$-type VGSC gene mutations in Sri Lankan whiteflies.

\section{CONCLUSIONS}

High percentages of the tested whitefly populations have developed resistance to the DOA recommended dosages of thiamethoxam (37-83\%), acetamiprid (50-83\%), imidacloprid (71\%), carbosulfan $(15-53 \%)$ and etofenprox (68-89\%) insecticides. Least resistance was shown to the organophosphate profenofos $(2-36 \%)$. Both the increased detoxification by esterases, glutathione S-transferases and monooxygenases, and AChE target site insensitivity contribute in varying degrees to the observed resistance. Involvement of kdr type mutations in pyrethroid resistance should be further investigated. This is the first report confirming the resistance status of Sri Lankan whiteflies with underlying resistance mechanisms and the outcome can be utilized effectively for developing a proper whitefly control programme in Sri Lanka avoiding indiscriminate use of insecticides.

\section{Acknowledgement}

Funding was provided from the National Agricultural Research Plan (NARP) for the project entitled 'Toxicity Levels of Selected Insecticides to Common Vegetable Pests'. Assistance given by S. Nawarathne for collection of insects, and the laboratory facilities provided by the Entomology Division of the Horticulture Crops Research and Development Institute, Gannoruwa and the Department of Zoology, Faculty of Science, University of Peradeniya are acknowledged.

\section{REFERENCES}

Abbott W.S. (1987). A method of computing the effectiveness of an insecticide. Journal of the American Mosquito Control Association 3(2): 302-303.

Basu A.N. (1995). Bemisia tabaci (Gennadius): Crop Pest and the Principal Whitefly Vector of Plant Viruses, p. 183. West View Press, New Delhi, India.

Bedford I.D., Briddon R.W., Brown J.K., Rosell R.C. \& Markham P.G. (1994). Geminivirus transmission and biological characterization of Bemisia tabaci (Gennadius) biotype from different geographic regions. Annals of Applied Biology 125: 311-325

DOI: https://doi.org/10.1111/j.1744-7348.1994.tb04972.x

Brødsgaard H.F. \& Albajes R. (1999). Insect and Mite Pests: Integrated Pest and Disease Management in Greenhouse Crops (eds. R. Albajes, M.L. Gullino, J.C. van Lenteren \& Y. Elad), pp. 48-60. Kluwer Academic Publishers, Dordrecht, Netherlands.

DOI: https://doi.org/10.1007/0-306-47585-5_4

Brogdon W.G., McAllister J.C. \& Vulule J.M. (1997). Heam peroxidase activity measured in single mosquitoes identifies individuals expressing an elevated oxidase for insecticide resistance. Journal of American Mosquito Association 13: 233.

Brown J.K. \& Bird J. (1992). Whitefly-transmitted geminiviruses and associated disorders in the Americas and the Caribbean Basin. Plant Disease 76 (3): 220-225.

Byrne F.J. \& Devonshire A.L. (1991). In vivo inhibition of esterase and acetylcholinesterase activities by profenofos treatments in the tobacco whiteßy Bemisia tabaci (Genn.): implications for the routine biochemical monitoring of these enzymes. Pesticide Biochemistry and Physiology 40: 198-204.

DOI: https://doi.org/10.1016/0048-3575(91)90090-9

Cahill M., Byrne F.J., Gorman K., Denholm I. \& Devonshire (1995). Pyrethroid and organophosphate resistance in the tobacco whitefly Bemisia tabaci (Homoptera: Aleyrodidae). Bulletin of Entomological Research 85: 181-187. DOI: https://doi.org/10.1017/S0007485300034258

Che-Mendoza A., Penilla R.P. \& Rodríguez D.A. (2008). Insecticide resistance and glutathione S-transferases in mosquitoes: A review. African Journal of Biotechnology 8(8): 1-12. 
Damayanthi B.T. \& Karunaratne S.H.P.P. (2005). Bichemical characterization of insecticide resistance in insect pests of vegetables and predatory ladybird beetles. Journal of the National Science Foundation of Sri Lanka 33(2): 115-122. DOI: https://doi.org/10.4038/jnsfsr.v33i2.2341

De Barro P.J., Liu S., Boykin L.M. \& Dinsdale A.B. (2011). Bemisia tabaci: A statement of species status. AnnualReview of Entomology 56: 1-19

DOA (2009). Pesticide Recommendations. Department of Agriculture, Gannoruwa, Peradeniya.

DOA (2015). Pesticide Recommendations. Department of Agriculture, Gannoruwa, Peradeniya.

Dittrich V. \& Ernst G.H. (1990). Resistance mechanisms in sweetpotato whitefly (Homoptera:Aleyrodidae) populations from Sudan, Turkey, Guatemala, and Nicaragua. Journal of Economic Entomology 83: 1665-1670.

DOI: https://doi.org/10.1093/jee/83.5.1665

Gorman K., Hewitt F., Denholm I. \& Devine G.J. (2002). New developments in insecticide resistance in the glasshouse whitefly (Trialeurodes vaporariorum) and the twospotted spider mite (Tetranychus urticae) in the UK. Pest Management Science 58: 123-130. DOI: https://doi.org/10.1002/ps.427

Gross A.D. \& Bloomquist J.R. (2018). Characterizing permethrin and etofenprox resistance $\mathrm{n}$ two common laboratory strains of Anopheles gambiae (Diptera: Culicidae). Insects 9(4): 146. DOI: https://doi.org/10.3390/insects9040146

Hemingway J. (1995). Efficacy of etofenprox against insecticide susceptible and resistant mosquito strains containing characterized resistance mechanisms. Medical and Veterinary Entomology 9(4): 423-426.

DOI: https://doi.org/10.1111/j.1365-2915.1995.tb00017.x

Hodges G.S. \& Evans G.A. (2005). An identification guide to the whiteflies (Hemiptera: Aleyrodidae) of the Southeastern United States. Florida Entomologist 88(4): 518-534.

DOI: https://doi.org/10.1653/0015-4040(2005)88[518:AI GTTW]2.0.CO;2

IRAC (2009). Insecticide resistance action committee susceptibility test methods series, method No. 008, version 3. Available at www. irac-online.org.

Kandil M.A., Saleh A.Y., Wafaa E.1., Dieb W.H. \& Farghaly S.F. (2008). Resistance mechanisms of whitefly Bemisia tabaci (Homoptera: Aleyrodidae) to thiamethoxam and profenofos. Asian Journal of Biological Sciences 1(1): 33-38.

DOI: https://doi.org/10.3923/ajbs.2008.33.38

Karatolos N. (2011). Molecular mechanisms of insecticide resistance in the glasshouse whitefly, Trialeurodes vaporariorum. PhD thesis. University of Exeter, UK.

Karunaratne S.H.P.P. (1998). Insecticide resistance in insects: A review. Ceylon Journal of Science (Biological Sciences) 26: 73-98.

Karunaratne S.H.P.P. \& Weerakoon K.C. (2007). Involvement of metabolic and insensitive acetylcholinesterase mechanisms in insecticide resistance of rice insect pests and predatory populations from Batalagoda, Sri Lanka. Journal of the
National Science Foundation of Sri Lanka 35(2): 103-108. DOI: https://doi.org/10.4038/jnsfsr.v35i2.3674

Karunaratne S.H.P.P., De Silva W.A.P.P., Weeraratne T.C. \& Surendran S.N. (2018). Insecticide resistance in mosquitoes: Development, mechanisms and monitoring. Ceylon Journal of Science 47(4): 299-309.

DOI: https://doi.org/10.4038/cjs.v47i4.7547

Karunker I., Benting J., Leuke B., Ponge T., Nauen R., Roditakis E., Vontas J., Gorman K., Denholm I. \& Morin S. (2008). Over-expression of cytochrome P450 CYP6CM1 is associated with high resistance to imidacloprid in the $\mathrm{B}$ and Q biotypes of Bemisia tabaci (Hemiptera: Aleyrodidae). Insect Biochemistry and Molecular Biology 38(6): 634-644.

DOI: https://doi.org/10.1016/j.ibmb.2008.03.008

Marasinghe J.P., Hemachandra K.S., Nugaliyadde L. \& Karunaratne S.H.P.P. (2017). Control failure of Sri Lankan whitefly (Bemisia tabaci Genn) is due to high resistance development against recommended insecticides. Journal of the National Science Foundation of Sri Lanka 45(1): 23-31.

DOI: https://doi.org/10.4038/jnsfsr.v45i1.8034

MOAAL (1997). Pesticide Recommendations. Department of Agriculture, Ministry of Agriculture and Lands, Sri Lanka.

Nauen R. \& Denholm I. (2005). Resistance of insect pests to neonicotinoid insecticides: current status and future prospects. Archives of Insect Biochemical Physiology 58: 200-215.

DOI: https://doi.org/10.1002/arch.20043

Perera M.D.B., Hemingway J. \& Karunaratne S.H.P.P. (2008). Multiple insecticide resistance mechanisms involving metabolic changes and insensitive target sites selected in anopheline vectors of malaria in Sri Lanka. Malaria Journal 7: 168 DOI: https://doi.org/10.1186/1475-2875-7-168

Surendran S.N., Marasinghe J.P., Gajapathy K., Tharmatha T., Sivabalakrishnan K., Weeraratne T.C. \& Karunaratne S.H.P.P. (2019). Genotyping of Bemisia tabaci (Hemiptera: Aleyrodidae) reveals the presence of two genetic groups in Sri Lanka. Journal of Entomological Science 54(2): 87-93. DOI: https://doi.org/10.18474/JES18-68

Vassiliou V., Emmanouilidou M., Perrakis A., Morou E., Vontas J., Tsagkarakou A. \& Roditakis E. (2011). Insecticide resistance in Bemisia tabaci from Cyprus. Insect Science 18: $30-39$. DOI: https://doi.org/10.1111/j.1744-7917.2010.01387.x

WHO (1998). Techniques to detect resistance mechanisms (field and laboratory manual). WHO/CDS/CPC/MAL/98.6, World Health Organization, Genewa, Switzerland.

WHO (2016). Test procedures for insecticide resistance monitoring in malaria vector mosquitoes. World Health Organization, Genewa, Switzerland.

Yang N., Xie W., Jones C.M., Bass C., Jiao X., Yang X., Liu B., Li R \& Zhang Y. (2013). Transcriptome profiling of the whitefly Bemisia tabaci reveals stage-specific gene expression signatures for Thiamethoxam resistance. Insect Molecular Biology 22(5): 485-496.

DOI: https://doi.org/10.1111/imb.12038 